\title{
Geological history, Ichnofacies and Sequence Stratigraphy of the Eocene - Oligocene Boundary at Sinjar Area, Northwestern Iraq
}

\author{
Majid. M. Al-Mutwali \\ Dept. of Petroleum and Refining Engineering \\ College of Petroleum Engineering and Mining \\ University of Mosul
}

\author{
Hiba A. Al-Rubai \\ Dept. of Geology \\ College of Sciences \\ University of Mosul
}

(Received 24/6/2020 ， Accepted 10/5/2021)

\begin{abstract}
Three outcrop sections for the Eocene- Oligocene boundary have been studied in Sinjar anticline northwestern Iraq. This study includes the lithostratigraphy, biostratigraphy and the identification of trace fossils and related ichnofacies in order to report the geological history of this boundary in the frame of sequence stratigraphy. Jaddala Formation, which is composed of marl and marly limestone, represents deep (outer shelf-upper bathyal) Eocene facies, Palani and Tarjil formations represent deposition in deep basinal environments during Early and Late Oligocene sequences.

The Eocene- Oligocene boundary in Sinjar area represents a disconformity surface, where the deposition ceased in the Middle Eocene (Lutetian) at the end of Jaddala Formation, forming the firmground Glossifungites Ichnofacies which embrace Thalassinoides ichnotaxa in Jaddala section, and the hardground Trypanites Ichnofacies in Sharafiddin section, while at Sinjar section, a chalky limestone bed deposited at the Early Oligocene (Rupelian) Palani Formation representing Skolithos Ichnofacies.

A rapid wide transgression took place at the end of Early Oligocene (Rupelian) leading to the deposition of Palani Formation, and continued through the Late Oligocene (Chattian) leading to the deposition of Tarjil Formation.

Keywords: Sinjar Formations, disconformity, Oligocene, Ichnofacies, biostratigraphy, lithostratigraphy.

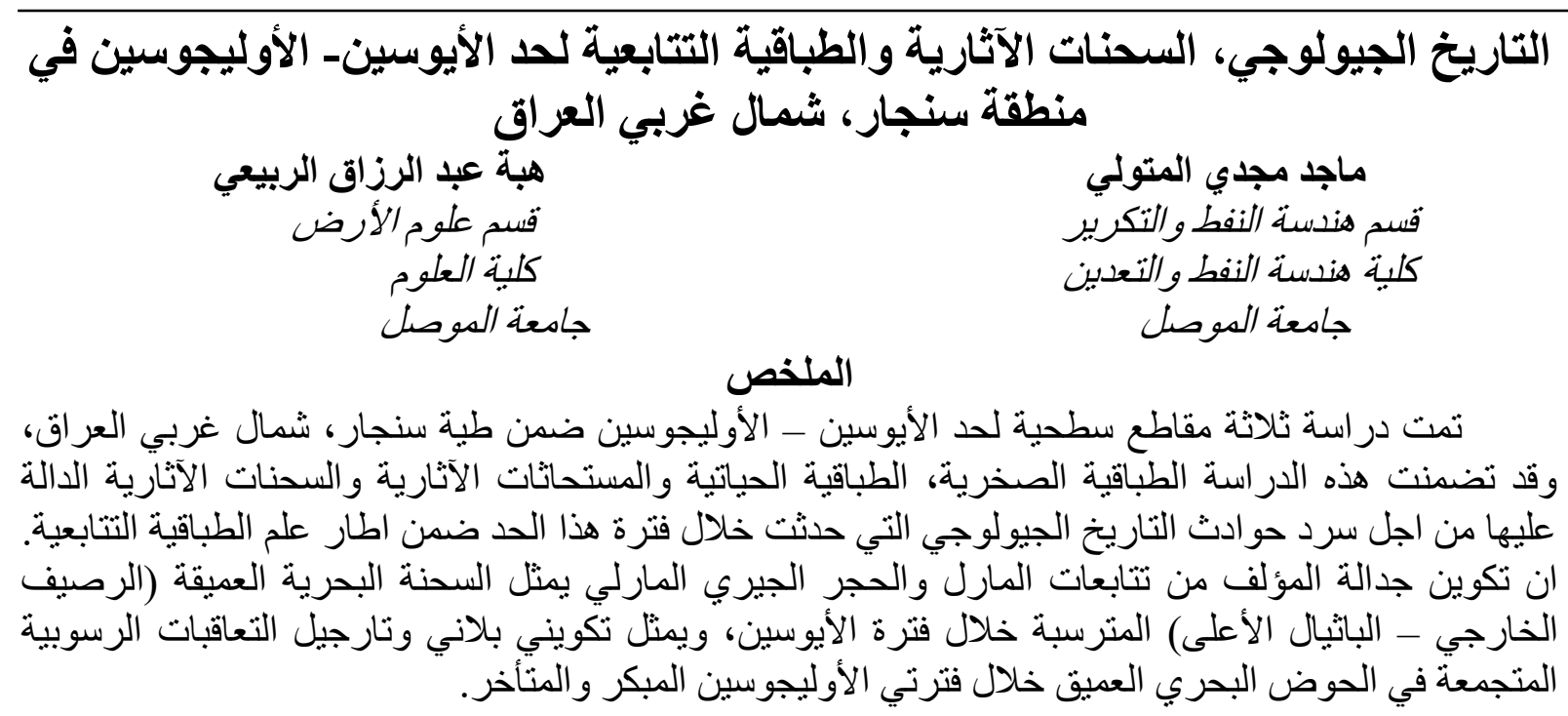




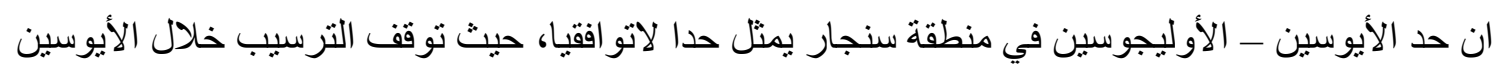
الأوسط (اللوتيتيان) مع نهاية ترسيب تلتابعات تكوين جدالة مكونا" السحنة الآثارية ( (Thalassinoides) الدالة على تكون الأرض المتماسكة والتي تميزت بسيادة الأثر الحياتئ (ichnofacies ضمن مقطع جدالة، اما في مقطع شرف الأين فتمثل الحد بوجود السحنة الآثارية (Trypanites ichnofacies)

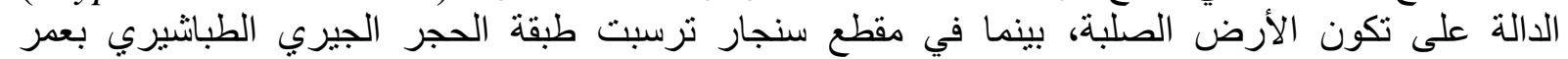

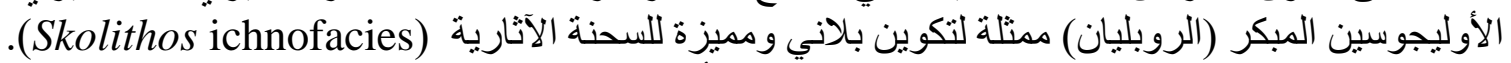

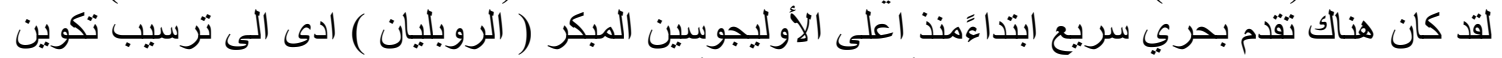

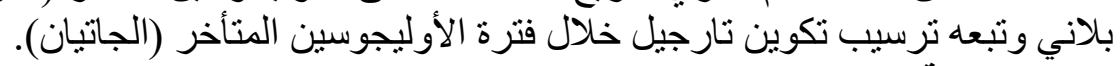

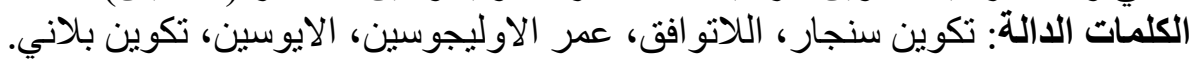

\section{INTRODUCTION}

A series of geological events has been occurred at the Eocene / Oligocene boundary on a worldwide scale, there is an important regression explaining that continuous sections are rare during this boundary, the Eocene/Oligocene boundary in Europe, which is marked by major discontinuities in all environments (Van Couvering et al., 1981). The Eocene /Oligocene boundary at Sinjar area is a discontinuity surface located between Jaddala Formation of Early - Middle Eocene age and the overlying Palani Formation of Early Oligocene age and Tarjil Formation of Late Oligocene age (Al-Rubai, 2017 and Al-Rubai and Al- Mutwali, 2020). Previous stratigraphic and paleontological studies indicated that Jaddala Formation was deposited in a deep open marine basin during late early - middle Eocene (Elewi, 1982; Al-Mutwali and AlBanna, 2002; Ismail, 2006, Al-Banna et al., 2010 and Al-Mutwali and Al-Sharbaty, 2012). According to Al-Hashimi and Amer (1985) Palani Formation is known in the low folded and Mesopotamian zones, including typical basinal facies rich in plankton foraminifera, which may be condensed and reduced to few meters in northwestern Iraq. Tarjil Formation occupies mostly the same areas of the former Palani Formation. The Eocene-Oligocene boundary is exposed along both limbs of Sinjar anticline.

The purpose of this paper is: (1) to give a detailed lithological description to the exposed studied sections of Eocene-Oligocene boundary, (2) to discuss the mechanisms responsible for trace fossils formation and types of ichnofacies that appear during this boundary with emphasis on erosional surfaces and associated Thalassinoides dominated firm ground; and (3) applying of these trace fossils and substrate-depending ichnofacies in sequence stratigraphic interpretation especially in the delineation of this sequence boundary.

\section{MATERIALS AND METHODOLOGY}

The current study about Eocene- Oligocene boundary depends on the fieldwork and laboratory studies. Three sections of this boundary have been chosen for present study, two of them located in the southern limb, Jaddala section ( $\mathrm{N} 36^{\circ} 18^{\prime} 24^{\prime \prime}, \mathrm{E} 41^{\circ}$ $\left.40^{\prime} 37^{\prime \prime}\right)$ and Sinjar section (N $41^{\circ} 50^{\prime}$, E $36^{\circ} 20^{\prime}$ ), the third one located in the northern limb Sharafiddin section (N $41^{\circ} 51^{\prime} 14^{\prime \prime}$, E $36^{\circ} 26^{\prime}$ 03") (Fig.1). During the fieldwork, the stratigraphic units are differentiated, the lithology of the sequences and trace fossils are described. The authors collected 68 samples from the studied sections for planktonic foraminiferal biostratigraphic study, about (30) g have been taken from each sample for foraminiferal analyses using classical method of washing (piking 
method), also 20 petrographic thin sections are prepared for microfacies studies.

\section{LITHOLOGIC DESCRIBTION}

The present study including Eocene-Oligocene sequences has been represented by Jaddala, Palani and Tarjil formations in three exposed sections (Jaddala, Sinjar and Sharafiddin). The studied sections are described lithologically based on field inspection.

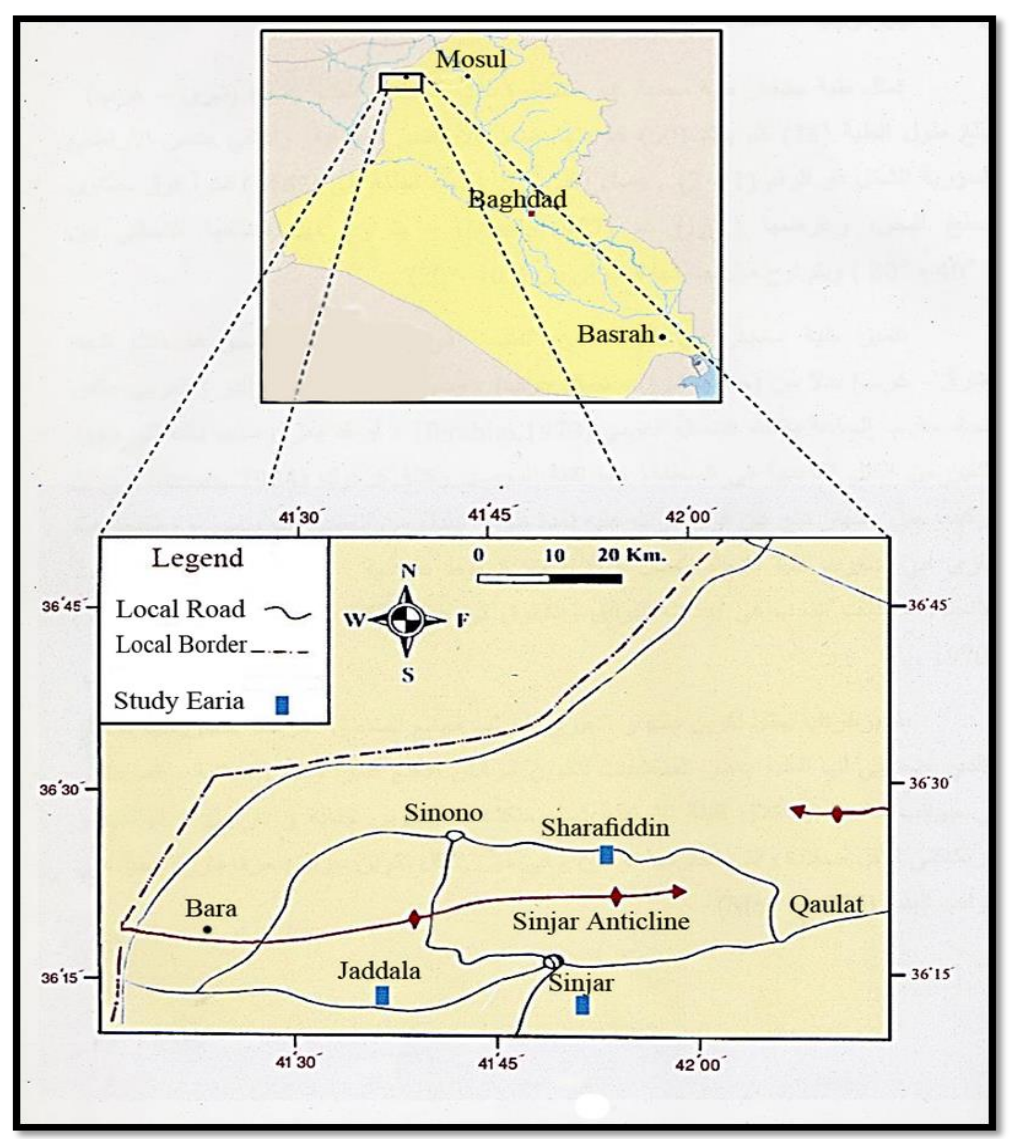

Fig.1: Location map of the studied sections.

\section{1-Jaddala section:}

The total studied thickness of this section is $(27.5 \mathrm{~m})$ including the uppermost part of the Jaddala Formation which is (8) m thick. It is represented from the base by (4.5) $\mathrm{m}$ sequence of white-yellow marly limestone beds of medium hardness containing little burrows of Thalassinoides (Fig.2), followed by (2.5) $\mathrm{m}$ of the same lithology characterized by distinctive increasing in Thalassinoides burrows (Fig.3), then thinly laminated pale grey marl bed of $(1 \mathrm{~m})$ thickness with high density of Thalassinoides burrows. Palani Formation (4.5 m thick) overlies Jaddala Formation unconformably, where it started by a basal conglomerate bed $(30 \mathrm{~cm}$ thick). It consists of extraclasts of chert, glauconite, magnetite, hematite, and sedimentary rock fragments, with mollusca shells and echinoid fossils, followed by white-yellowish limestone bed $(50 \mathrm{~cm}$ thick) then light gray friable marl bed $(1 \mathrm{~m}$ thick); these beds contain detritus chert, glauconite and iron oxides showing fining-upward grain size, 
with some transported litoclasts (Fig.4). Upwards comes intercalation of marl and marly limestone beds about $(2.5 \mathrm{~m})$ thick continued towards the end of the Palani Formation. Tarjil Formation overlies Palani Formation conformably where the studied lower part of Tarjil Formation (15m thick) consists of $3 \mathrm{~m}$ thick of pale brown marly limestone and then $12 \mathrm{~m}$ thick alternation of hard marly limestone and marl.

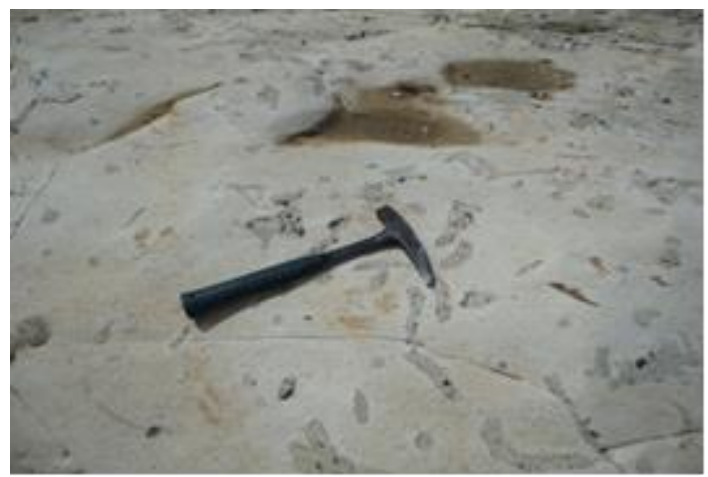

Fig.2: Marly limestone bed at the upper part of Jaddala Formation containing little Thalassinoides burrows (Jaddala section).
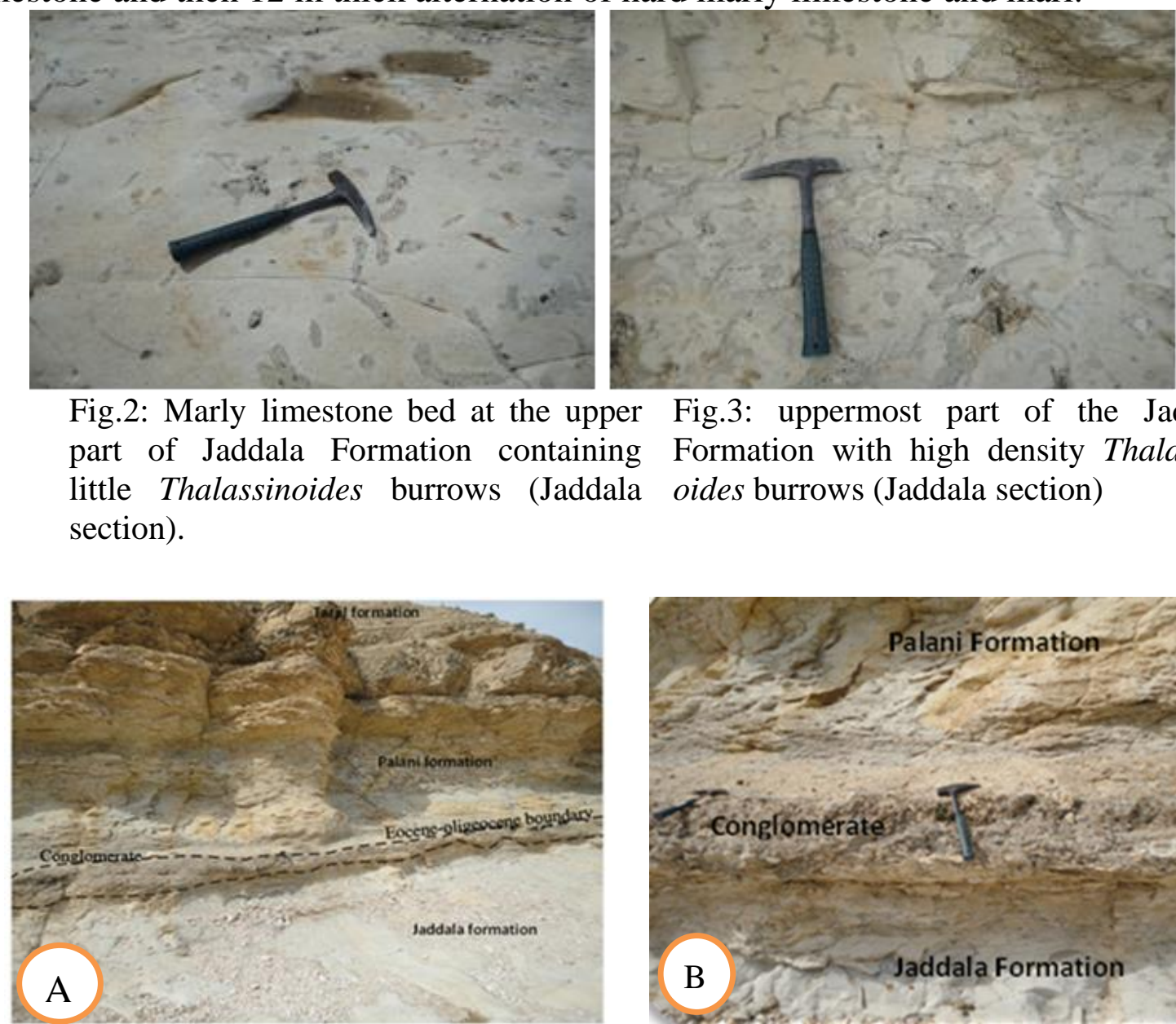

Fig.3: uppermost part of the Jaddala Formation with high density Thalassinoides burrows (Jaddala section)

Fig.4: Eocene-Oligocene boundary at Jaddala section (A) view of the outcrop showing the formations below and over this boundary. (B) Close-up photo showing the

\section{2- Sinjar section:}

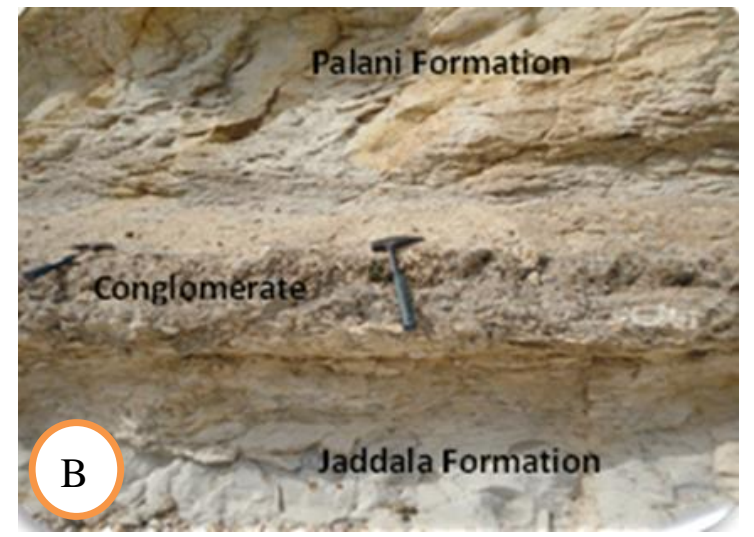

The total studied thickness of this section is $(15.5 \mathrm{~m})$ including $(1 \mathrm{~m})$ from the uppermost part of Jaddala Formation, (4m) Palani Formation and (10.5 m) Tarjil Formation. Jaddala Formation is composed of light brown marly limestone bed, while Palani Formation which overlies the Jaddala Formation unconformably consist of (2 m) soft white - pale grey chalky limestone bed which formed of sandy size carbonate particles containing some trace fossils like Skolithos and planolites (Figs.5), also there is sedimentary structure in a form of cross bedding, followed by $(2 \mathrm{~m})$ pale brown thinly laminated marly limestone bed. Tarjil Formation consists of thinly laminated hard white-pale brown intercalation of marly limestone and marl beds. 


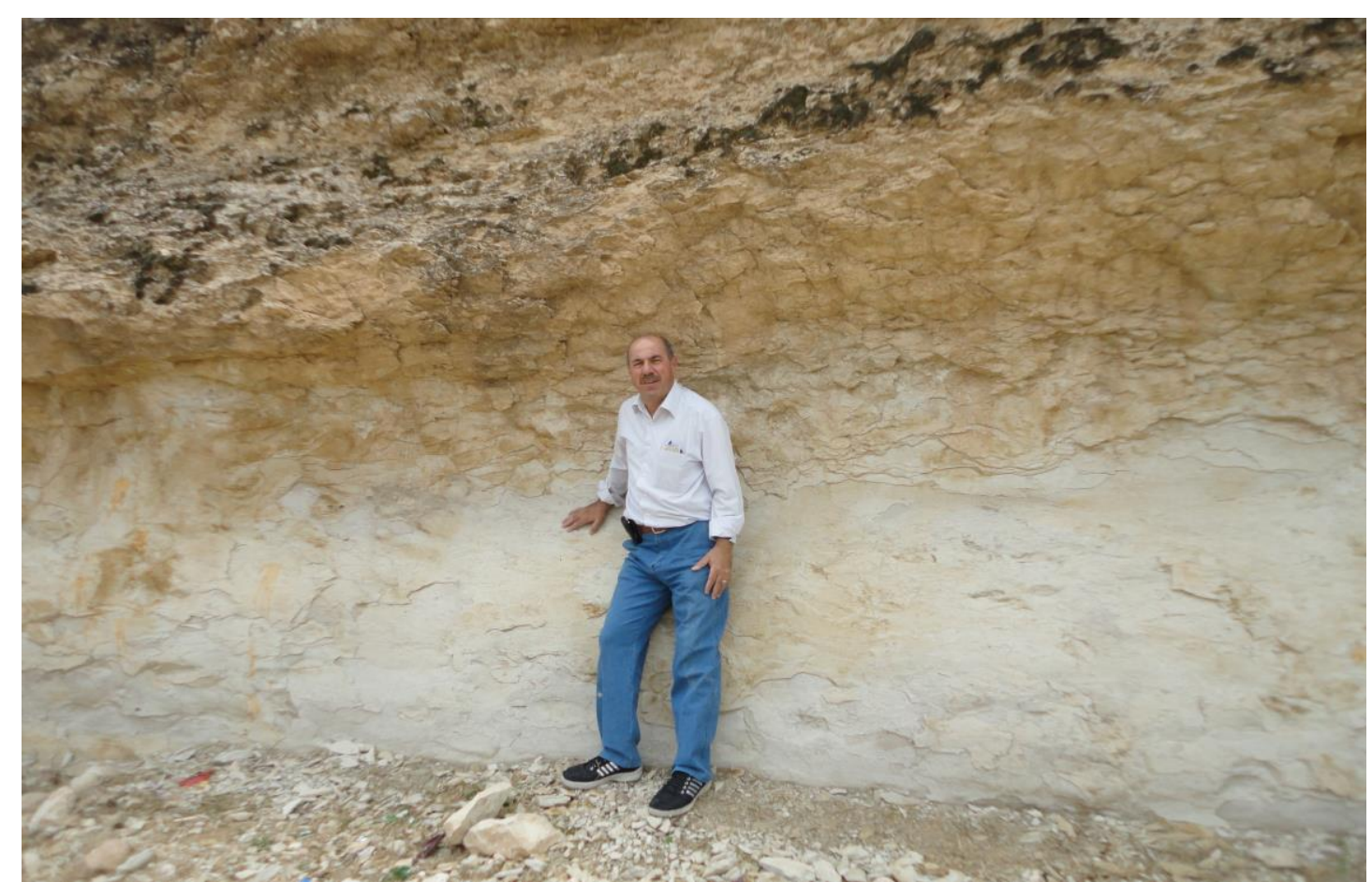

Fig.5: The white soft chalky limestone bed at the base of Palani Formation (Early

Oligocene) in Sinjar section.

\section{3- Sharafiddin section:}

The total studied thickness of this section is $(81 \mathrm{~m})$ including Jaddala Formation $(42 \mathrm{~m})$, Palani Formation $(11 \mathrm{~m})$ and Tarjil Formation $(28 \mathrm{~m})$. Jaddala Formation is mainly composed of intercalation of pale grey marl and pale brown marly limestone for the lower $35 \mathrm{~m}$, then appears thinly bedded marl bed (1m thick), after that sequence of pale brown marly limestone continue to the end of the formation. Jaddala Formation terminates by a conglomerate bed ( $3 \mathrm{~cm}$ thick) (Figs. 6 and 7), which contains fragments of chert, iron oxides. Unlined cylindrical vase- shaped domiciles appear within this bed, the upper surface of this bed is mantled by casts and molds of pelecypoda shells which may be the causative for these dwelling traces. This bed represents a hard ground surface (Trypanites Ichnofacies) at the Eocene- Oligocene boundary in Sharafiddin section. Palani Formation overlies Jaddala Formation unconformably where it is formed from repetition of marl and marly limestone. Tarjil Formation is also composed of repetition of pale grey marl and pale brown marly limestone. The separation between Palani Formation and Tarjil Formation deposits in Sharafiddin section is difficult to distinguish because of the similarity in lithofacies of the two studied formations, but it seems that the deposits of Tarjil Formation are more hardened. 


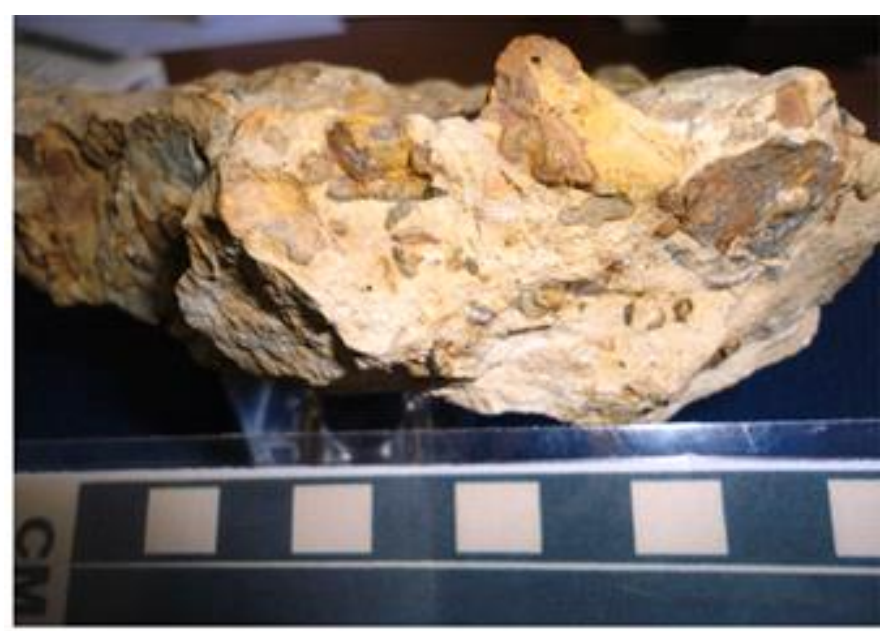

Fig. 6:Vertical section of thin limestone bed appear at the Eocene-Oligocene boundary at Sharafiddin section contains boring and tier dwelling structures filled by iron oxides represent hard ground lithified carbonate surface (Trypanites Ichnofacies).

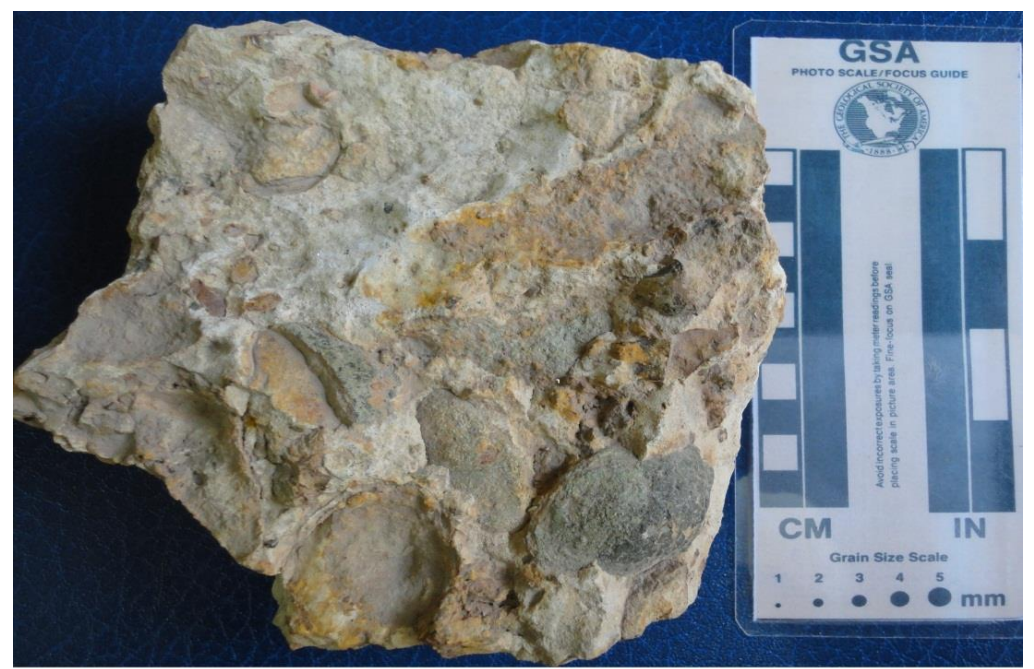

Fig.7: The upper surface of the same thin limestone bed which appear at the Eocene-

Oligocene boundary at Sharafiddin section plastered by Pelecypoda (oysters) representing a hardground disconformity surface.

\section{BIOSTRATIGRAPHY}

The Eocene - Oligocene rocks exposed in Sinjar area are represented by Jaddala, Palani and Tarjil Formations, which consist of deep-marine carbonates yielded abundant planktonic foraminifera. Depending on the planktonic foraminiferal biostratigraphy of the studied Eocene-Oligocene successions (Al- Rubai, 2017 and AlRubai and Al-Mutwali, 2020), two zones were identified within the studied three sections based on the zonal scheme of Toumarkine and Luterbacher (1985), P11 in Jaddala Formation, P19 in Palani Formation. The Globigerinatheka subconglobata subconglobata Zone (P11) represent Middle Eocene (Lutetian) age. It is defined as a partial range of the zonal marker from first occurrence of Globigerinatheka mexicana mexicana to last occurrence of Morozovella aragonensis. This zone is recognized in the upper part of Jaddala Formation. The lower boundary of this zone is not included in this study, the top of this zone is well defined by the last occurrence of $\mathrm{M}$. 
aragonensis and other Middle Eocene planktonic foraminiferal species belonging to Turborotalia, Acarinina, Truncorotaloides, Globigerinatheka, Hantkenina and Morozovella. The Pseudohastigerina micra Interval Zone (P 19) which indicates Upper Early Oligocene age (Rupelian) is represented by the range of the nominate taxon between the last occurrence of Middle Eocene planktonic foraminiferal species belonging to Turborotalia, Acarinina, Truncorotaloides, Globigerinatheka, Hantkenina and Morozovella at the base with the last occurrence of the nominate taxon at the top. This zone is restricted to Palani Formation, where its lower boundary represents the unconformable surface between Jaddala Formation (Middle Eocene) and Palani Formation (Early Oligocene), while its upper boundary represents the conformable contact between Palani Formation and Tarjil Formation. The hiatus (about 9 My) between Eocene-Oligocene deposits is designated by the absence of the following zones: M. lehneri Zone (P12), O. beckmanni Zone (P13), Trun. rohi Zone (P14), Glgthk. semiinvoluta Zone (P15+ Lower part of P16), Tub. cerroazulensis Zone (P17 + Upper part of P16) and Cassigerinella chipolensis Zone (P18). The species Cs. Chipolensis are not recorded in this study, so we depend on the last occurrence of the index species Psh. micra to delineate the upper boundary of Psh.micra Zone corresponding to the Mancini and Waters, 1986.

\section{ICHNOFACIES OF THE EOCENE-OLIGOCENE BOUNARY AT SINJAR AREA}

Trace fossils, consisting of fossil tracks, trails, burrows, borings and other products of organismal behavior, reflect basic patterns of behavior such as: resting, feeding, crawling, grazing and dwelling traces, and because trace fossils ordinarily are not subject to transport from their site of formation, so they have been used as good indicators for ancient environmental conditions, paleoecology, sedimentology, and stratigraphy (Seilacher, 1967; Frey, 1975; Curran, 1985; Pemberton et al., 1992). For more than 50 years, researchers in Ichnology describe and use ancient and recent traces for the conclusions concerning mainly the environmental reconstructions. During the last 25 years, the dependence on Ichnology has begun to be used in sequence stratigraphy. The Ichnofacies, which represent a group of trace fossils that exist together within certain spatial environments, have been particularly instrumental in testing identifications of: sequence boundaries (unconformities and their conformable equivalents), linked with regressions; maximum flooding surfaces associated with transgressions; and condensed sections caused by slow sedimentation rates (Pemberton et al., 1992, 2004; MacEachern et al., 2007and Martin, 2009). Trace fossils contribute in the distinction of sequence boundaries, which are often represent omission surfaces, as well as they help in the correlation of laterally adjacent facies, hence better defining transgressive - and regressive system tract sequences (Martin, 2009).

In general, the process of determining sequence boundaries through the ichnofacies must be carried out by studying and following it sideways for long distances and vertically within the stratigraphic sequence (Seilacher, 1967).

MacEachern et al. (2007) and Martin (2009) stated that the most useful ichnofacies in sequence stratigraphy are substrate-controlled, in which the available substrate limited the types of trace makers and their modes of trace making. These 
substrate-dependent ichnofacies include: 1-Trypanites Ichnofacies characteristic of fully lithified marine substrates, 2- Teredolites Ichnofacies encompasses suites of borings excavated into woody or coaly substrates and 3-Glossifungites Ichnofacies which is characteristic of firm but unlithified substrates. All of these three ichnofacies are normally associated with non-depositional or erosional breaks, and hence may be considered as indicators of stratigraphic discontinuities.

The lateral recognition of the Eocene-Oligocene stratigraphic boundary in the studied section, which is determined based on the substrate - controlled ichnofacies, can serve as a good sequence boundary, where the recognition of this stratigraphic breaks is essential in the sequence stratigraphic paradigm, it is also vital in resolving the depositional environments of associated deposits, and in determining the allocyclic controls on the depositional systems (MacEachern et al., 2007).

\section{GEOLOGICAL HISTORY AND SEQUENCE STRATIGRAPHY OF THE EOCENE-OLIGOCENE BOUNDARY IN SINJAR AREA}

There is no doubt that the sequence boundaries, which represent unconformity surfaces, indicate that there are many hiatuses in a geological age. They represent an important problem in geology that requires a great deal of different specialties in stratigraphy, sedimentology, paleontology and ichnology to elucidate the geological history and the sequences of the events that happened during this mysterious time. The Eocene-Oligocene boundary in Sinjar area is a good example for this state, where the interpretation of this boundary adds important information about the geological events that affected the sedimentary basin and recorded within their chronological sequences giving their relative ages. The sedimentary rocks laying under and over the EoceneOligocene boundary in Sinjar area show many stratigraphical and paleontological evidences, which indicate that there is variations that can be inferred in lithology, foraminiferal assemblages, trace fossils and ancient sedimentary environments through this boundary. All these variations are studied within these rocks, which provide valuable information for sedimentation through it.

During the Early-Middle Eocene (Yapresian-Lutetian) time, the Jaddala Formation had been accumulated in the whole Sinjar area, represented by marl and marly limestone rocks deposited in the middle shelf-upper bathyal environments, which is characterized by dominant existence of planktonic and benthonic foraminiferal assemblages. The definite planktonic foraminiferal zones show that the age of this formation ranges from Early Eocene (zone P7) to the Middle Eocene (zone p11) (Al- Mutwali and Al-Banna, 2002). This age is also confirmed in the current study, where the upper sequences of Jaddala Formation deposited during the Middle Eocene (Lutetian) Globigerinatheka subconglobata Zone P11). This zone is not completed in the studied sections because the deposition had been stopped throughout the Sinjar area at the top of this zone during the Middle Eocene age (Lutetian). The reason for this case in deposition between Jaddala Formation and the overlying Oligocene deposits is due to tectonic cause (uplifting) coincided with a forced regression in sea level. These factors lead to the existence of disconformity in EoceneOligocene boundary at Sinjar area. For the purpose of describing this boundary, the geological history will be listed for the studied three sections starting from the oldest to the youngest sequences, its status will be described within each section by dividing 
the column in each section into three parts: the lower part that represents the sediments falling under the surface of disconformity represented by the uppermost part of Jaddala Formation; the middle part that assimilates the boundary itself; and the upper part that represents the sediments located on the top of the disconformity surface belonging to the Palani or Tarjil Formations of Early and Late Oligocene age.

\section{1- Jaddala section:}

The field evidences show a clear disconformity surface during EoceneOligocene boundary in this section, which represents a sequence boundary type 1 associated with the recognition of substrate-controlled Glossifungites ichnofacies. The uppermost Middle Eocene sequences of Jaddala Formation are defined by pale grey thin soft platy marlstone beds accumulated during the highstand system tract, these beds show densely existence of Thalassinoides burrow system. The Thalassinoides consist of branches of cylindrical or (Y)-shaped burrow system, straight or curved, commonly penetrate deeply (up to $2 \mathrm{~m}$ ) below the associated discontinuity in firm, unlithified substrates. The average length of each burrow system is $15-50 \mathrm{~cm}$ with a diameter range between $2-4 \mathrm{~cm}$ (Fig.8). The Thalassinoides are characterized by unlined sharp walls, but may be reinforced entirely by mucus lining to prevent their collapse (Myrow, 1995). Later characteristic demonstrates that these structures remained open after being vacated by the tracemaker, thus allowing material from subsequent depositional events to accumulate therein (MacEachern et al., 2007), so it was observed that there is a clear difference in the nature of sediment fillings the burrows from the sediments surrounding it (Fig. 9), where the burrows filled with rough volumes deposits consisting mainly of carbonates, rock fragments, chert, iron oxides, as well as pyrite and green glauconite with a little bit of quartz and tests of planktonic and benthonic foraminifera.

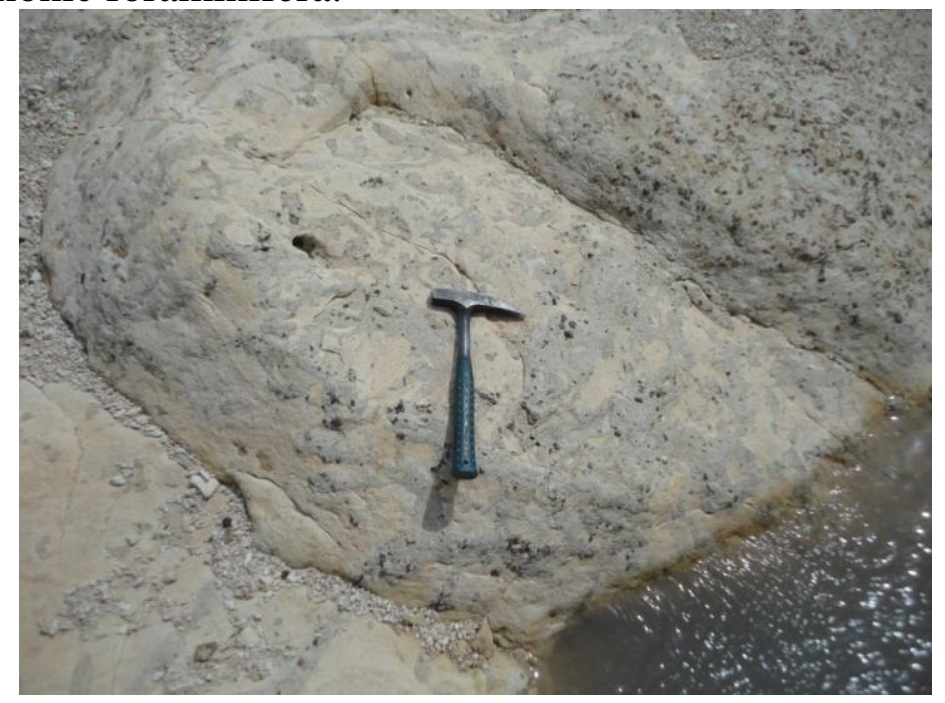

Fig.8: The surface of the Eocene-Oligocene boundary in Jaddala section showing condensed Thalassinoides burrow systems. 


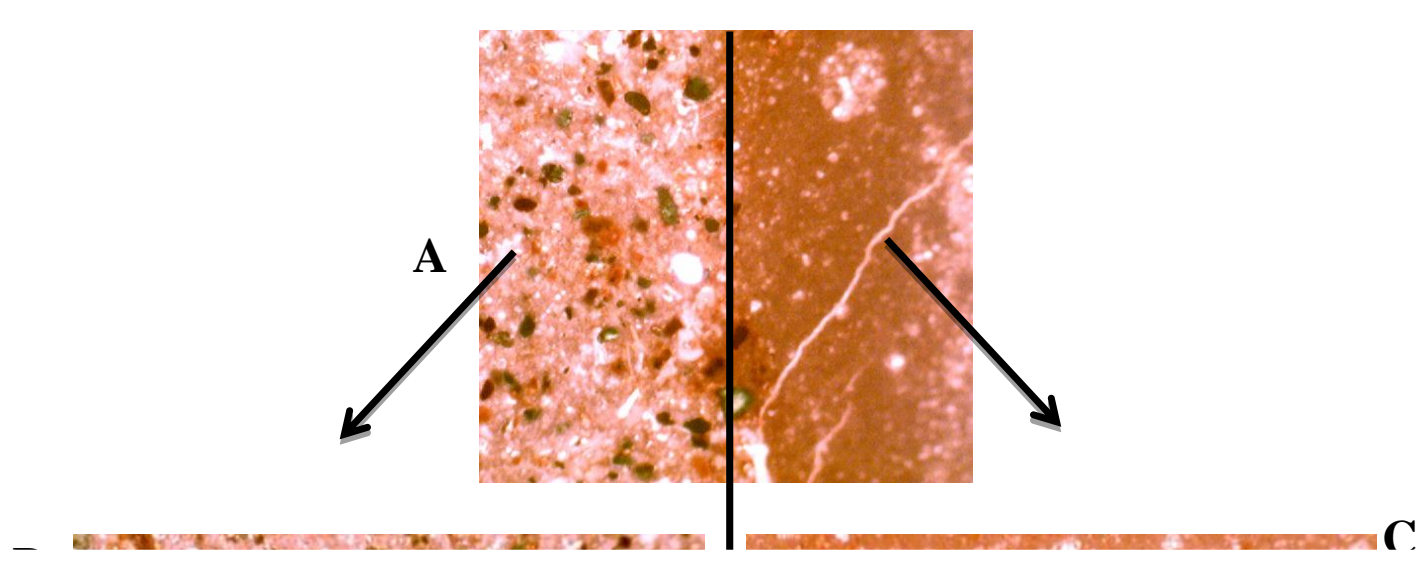

Fig.9: A: Photo showing the boundary between the infilling sediments in Thalassinoides (left) and surrounding sediments (right). B: Close -up photo to the sediments inside Thalassinoides. C: Close -up photo to the sediments surrounding

Thalassinoides consisting of planktonic foraminiferal -wackestone microfacies.

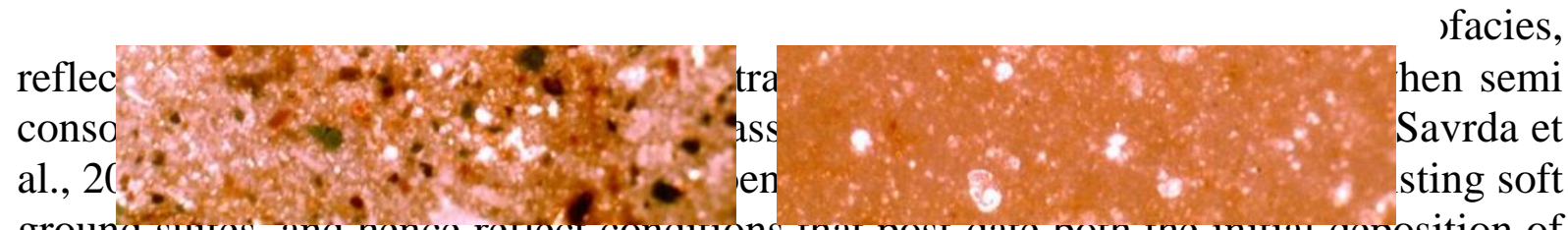
ground suites, ana nence rerlect conditions that post-date both the initial deposition of the unit and the erosion of that unit. These omission suites actually correspond to the period of time between the erosional event (which exhumes the substrate) and final burial of the discontinuity beyond reach of the benthic community of the overlying unit. During such a hiatus, infaunal organisms are free to colonize the substrate, were the specific characteristics of the ichnofauna are thus determined by the nature of the substrate and the paleoenvironmental conditions prevailing during the hiatus (Pemberton et al., 2004).

The Glossifungites Ichnofacies is environmentally wide ranging, but only develops in firm, unlithified substrates such as dewatered muds or compacted sands. Dewatering is resulted from burial, and the substrates are made available to trace makers when exhumed by later erosion. Exhumation can occur in terrestrial environments as a channel meandering or valley incision, in shallow- water environments as a result of migrating tidal and other channels, coastal erosion or erosive shoreface retreat, and in deep water, related to submarine canyon erosion (Pemberton and Frey, 1985; Pemberton et al., 2004; Savrda et al., 2001; MacEachern et al., 2007). Such horizons commonly form at bounding discontinuities and are critical in sequence stratigraphic reconstructions of the rock record (MacEachern et al., 2007).

The scenario, that we believe in, happened during the Middle Eocene at the uppermost part of Jaddala Formation, where the sedimentation stopped during this time, and sudden decline in sea-level occurred, which may synchronize with uplift of the sedimentary basin due to tectonic events affected the whole Sinjar area. All these effects led to erosion and removal of bottom sediments and loss of time. This state of exposure and erosion of the continental shelf made this surface a sequence boundary of type 1, also the cease of sedimentation and the exposure of the sedimentary basin led to its cohesion to become a semilithified substrate in Jaddala section and then colonized by organisms to form Thalassinoides burrows indicating a Glossifungites 
ichnofacies, or the cohesive substrate becomes completely rigid to form the hard ground (Trypanites Ichnofacies) as in Sharafiddin section. The Glossifungites Ichnofacies in Jaddala section is superimposed at the top of the Jaddala Formation sediments, where Thalassinoides burrows emplaced beneath the Eocene-Oligocene sequence boundary, these burrows are generally sharp-walled and unlined, reflecting the stable, cohesive nature of the substrate at the time of colonization and burrow excavation, furthermore the passive nature of most burrow fills. This confirms that the structure remained open after the trace-maker vacated the domicile, thus allowing material from subsequent depositional events to infiltrate the open tube (Pemberton et al., 2004). The disconformity Eocene-Oligocene sequence boundary surface in Jaddala section is overlain by a low thickness conglomerate lag deposits bed (30 $\mathrm{cm}$ thick), which represents the erosion products that accumulate during Early Oligocene age at the lower part of Palani Formation, representing the lowstand system tract (LST) of the subsequent new sequence that started at the Early Oligocene (Al-Banna and AlMutwali, 2002). This bed is composed of carbonate sand size with some rock fragments, iron oxides and glauconite, with the existence of planktonic and benthonic foraminifera, these materials fill the Thalassinoides burrows, so we can see a great difference between these filling materials and the surrounding sediments. The upper surface of conglomerate bed represents the transgressive surface of the sequence, where over it the sediments of Early Oligocene (Rupelian) transgressive system tract are deposited. The TST deposits are composed of detrital limestone - marl and marly limestone with dispersed pebbles of glauconite and iron oxides.

It should be noted that the high concentration of glauconite distinguish the case of sediment starvation (Udgata, 2007). This happened in Jaddala section due to rapid transgression and flooding of the sea at the beginning of the sequence which started at the upper Early Oligocene (Rupelian) time, then there is a gradual reduction in the concentration of glauconite upwards as the sediments precipitated within the TST, where the sedimentary conditions return to its normal state within this part of the basin (Fig.10).

\section{2-Sinjar section:}

This section is located to the east of Jaddala section and it is about $15 \mathrm{~km}$ away. The Eocene-Oligocene boundary in this section is located above the last marly limestone belonging to Jaddala Formation, which has medium hardness and light brown color containing planktonic foraminiferal assemblages of the Middle Eocene (Lutetian) age (Globigerinatheka subconglobata subconglobata Zone P11). Above this boundary, first Early Oligocene (Rupelian) deposits are situated, which are composed of fragile chalky limestone bed ( $2 \mathrm{~m}$ thick) of pale white-light grey color, consisting of carbonate sand-size granules very rich with good preserved planktonic and benthonic foraminifera, and containing many trace fossils like Skolithos, Planolites, Ophiomorpha (Fig.11).

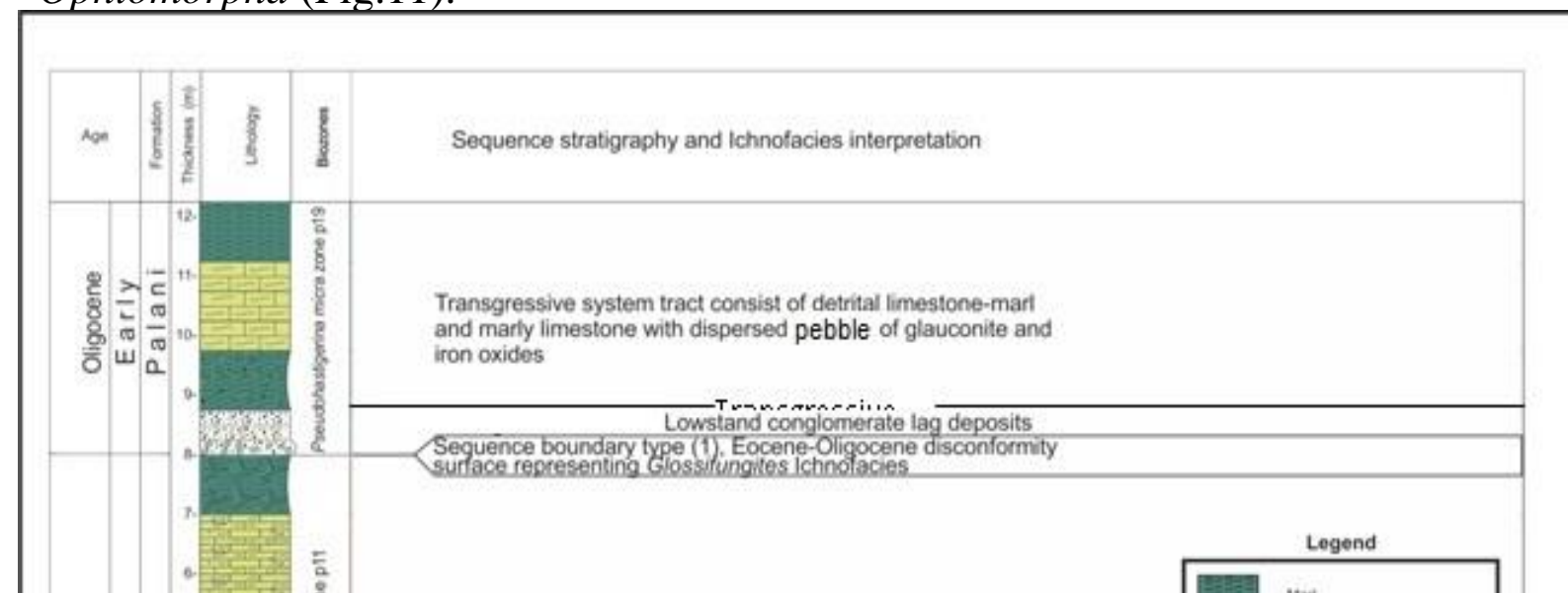


It is worth to mention that the conglomerate bed located at the base of Palani Formation at Jaddala section disappears in Sinjar section, this means that the lag deposits of weathering which precipitated in Early Oligocene (Rupelian) did not reach this area within the basin of deposition indicating that Sinjar section represents a relatively deeper marine area than Jaddala section. Instead, a soft chalky limestone bed had been precipitated ( $2 \mathrm{~m}$ thick) during the Early Oligocene (Rupelian) assimilating Palani Formation; this bed represents the lowstand system tract of the Oligocene sequence, which consists of sand size carbonates deposited in middle shelf environments with the effect of active marine current on the basement caused the winnowing of fine materials and the formation of cross bedded structure (Fig.12). This conclusion is supported by the fact that this chalky limestone bed contains high abundance of planktonic foraminifera and lesser proportion of benthonic foraminifera, and all of them are well preserved.

The lithological characteristics and sedimentological structures of this chalky limestone bed and the existence of trace fossils Skolithos, Planolites, Ophiomorpha within it indicate Skolithos ichnofacies. Seilacher (1967) and Mac Eachern et al. (2007) benefit that the Skolithos ichnofacies is indicative of relatively high levels of wave or current energy, and is typically developed in clean, well-sorted, loose or shifting particulate substrates, were abrupt changes in rates of deposition, erosion, and physical reworking of sediments are characteristic. Such conditions commonly occur at the shoreface and sheltered foreshores. Similar conditions may occur in a wide range of depositional environments, where the Skolithos ichnofacies may appear in slightly to substantially deeper-water deposits, wherever energy levels, food supplies, and / or hydrographic and substrate characteristics are suitable, like submarine canyons, deep-sea fans, and bathyal slopes swept by strong contour currents (Crimes et al., 1981).

The Eocene-Oligocene boundary in Sinjar section represents a sequence boundary type 1, where the chalky limestone bed, which indicates Skolithos Ichnofacies directly overlies this boundary representing the lowstand system tract of the Oligocene sequence the upper boundary of this bed representinga a transgressive 
surface above it where the sediments belonging to transgressive system tract are located (Fig. 13) .
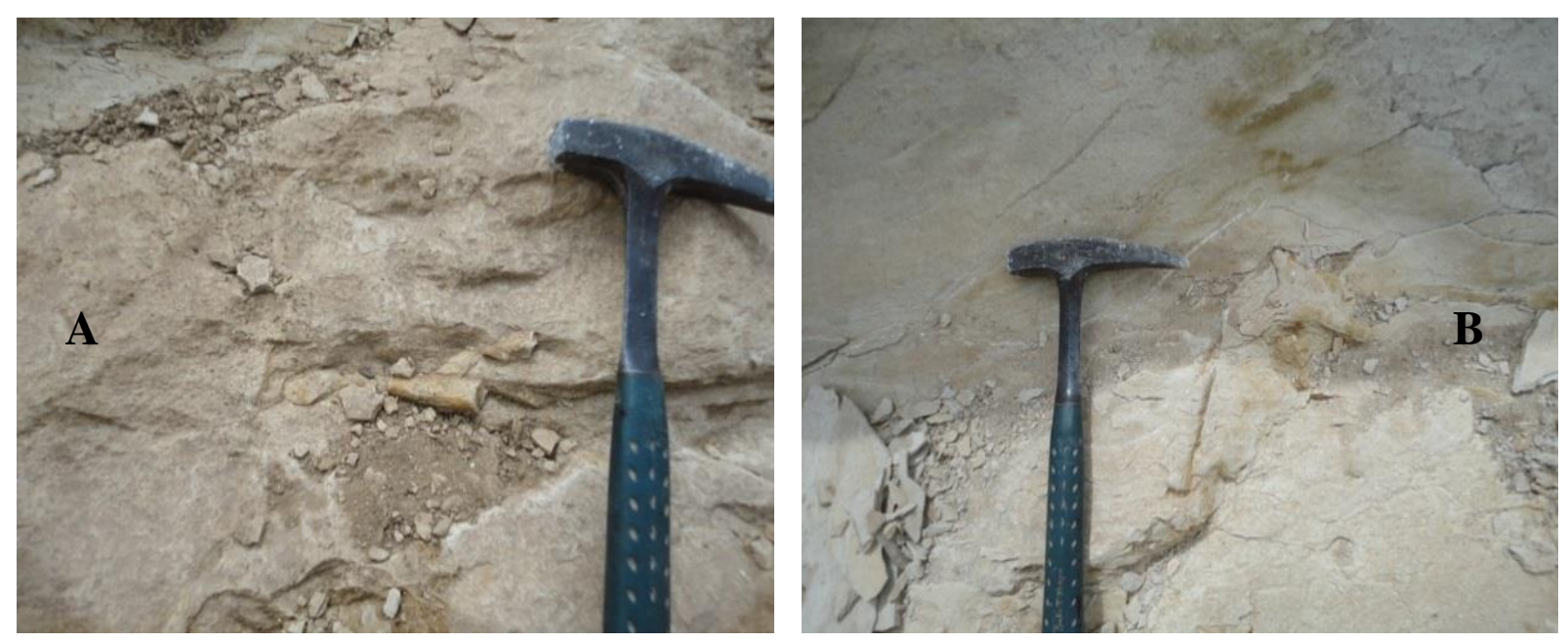

Fig.11: Trace fossils wl bed at the lower part of
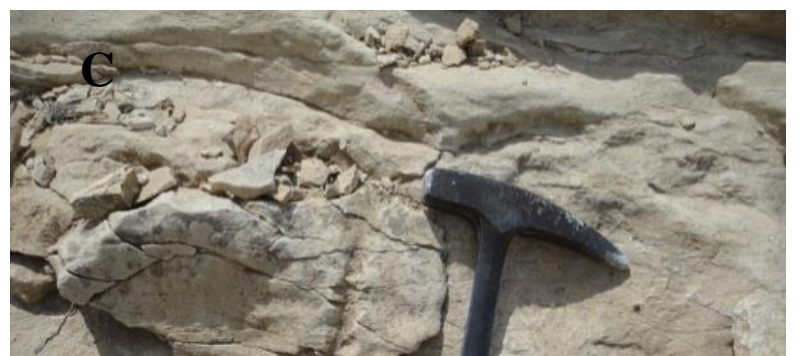

the chalky limestone nolites, B: Skolithos,

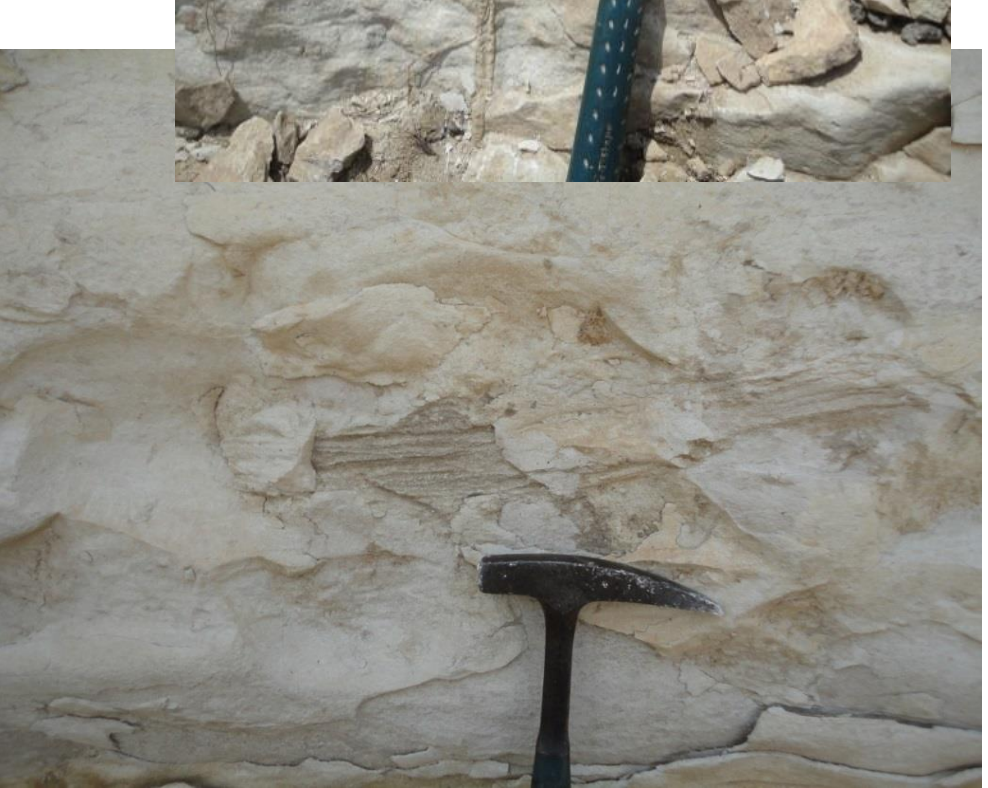

Fig.12: Cross bedding in the chalky limestone bed at the lower part of Palani formation in Sinjar section.

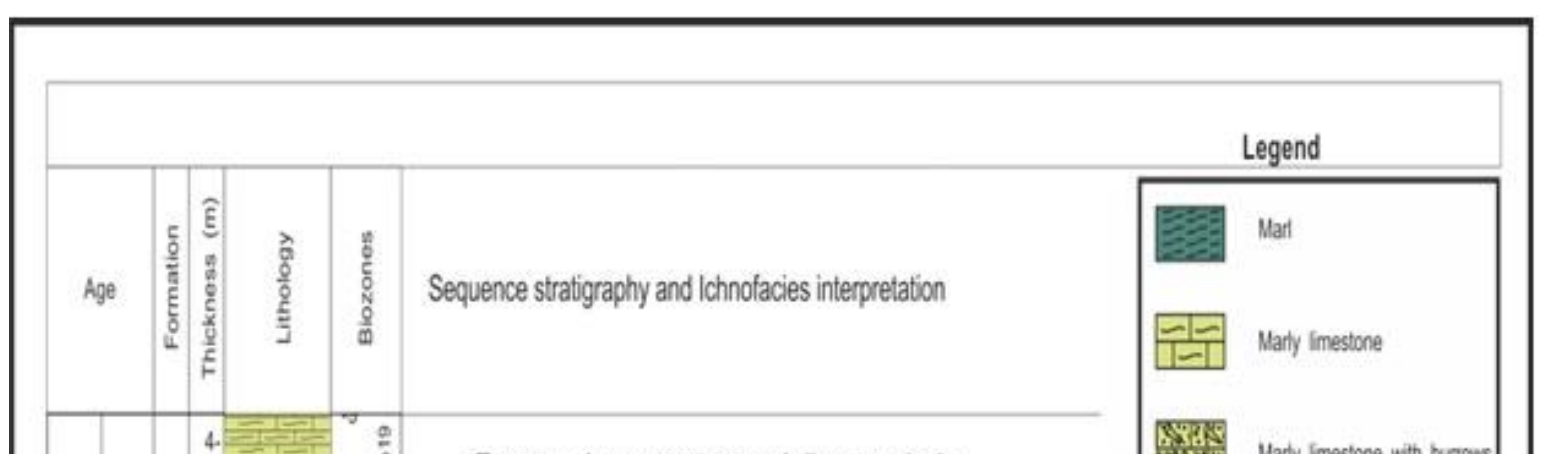




\section{3-Sharafiddin section:}

The field locating of the Eocene-Oligocene boundary in Sharafiddin section is difficult, because there is a similarity in lithological components between the middle Eocene deposits (Jaddala Formation) and the overlaying Oligocene deposits (Palani Formation), where both formations are composed of marl and marly limestone strata. So, in order to locate this boundary, it is necessary to do a precise field work to observe any lithological variations, in addition to recourse to planktonic foraminifera, where there is a clear change in the planktonic foraminiferal assemblages from the middle Eocene (Lutetian) (P11) to Early Oligocene (Rupelian) (P19).

At this boundary a thin hardground limestone bed $(3 \mathrm{~cm}$ thick) occur at the uppermost part of the Jaddala Formation, where its upper boundary represents the Eocene-Oligocene disconformity surface, assimilating a sequence boundary type 1 . This thin bed is composed of white to pale yellow limestone characterized by the presence of cylindrical, vase or irregular borings and galleries filled with reddishbrown deposits with iron oxides, which indicate a long-term bioerosion of a lithified carbonate surface with no contemporaneous sedimentation (Trypanites ichnofacies). On the upper surface of this bed, pelecypoda shells (Oyster) exist, where these organisms need a hard solid surface to attach on it. This confirms the hardground Trypanites ichnofacies, and it is a good indicator for the Eocene-Oligocene disconformity sequence boundary surface in the field in Sharafiddin section. It should be noticed that the little thickness of this bed and the absence of lowstand system tract in this section may be due to the erosion that affect this surface during the early transgression that happened in the Early Oligocene, where this caused the formation of a transgressive surface of erosion, which removed the lowstand system tract deposits, and caused the existence of encrusting pelecypods to colonize this hard surface in a costal shallow marine environments, so the Eocene-Oligocene boundary in this section represents a sequence boundary and a transgressive surface at the same time due to the 
absence of the lowstand system tract deposits. This boundary is overlain by marl and marly limestone beds which were accumulated throughout the transgressive system tract during the Early Oligocene (Rupelian) (Palani Formation) (Fig.14).

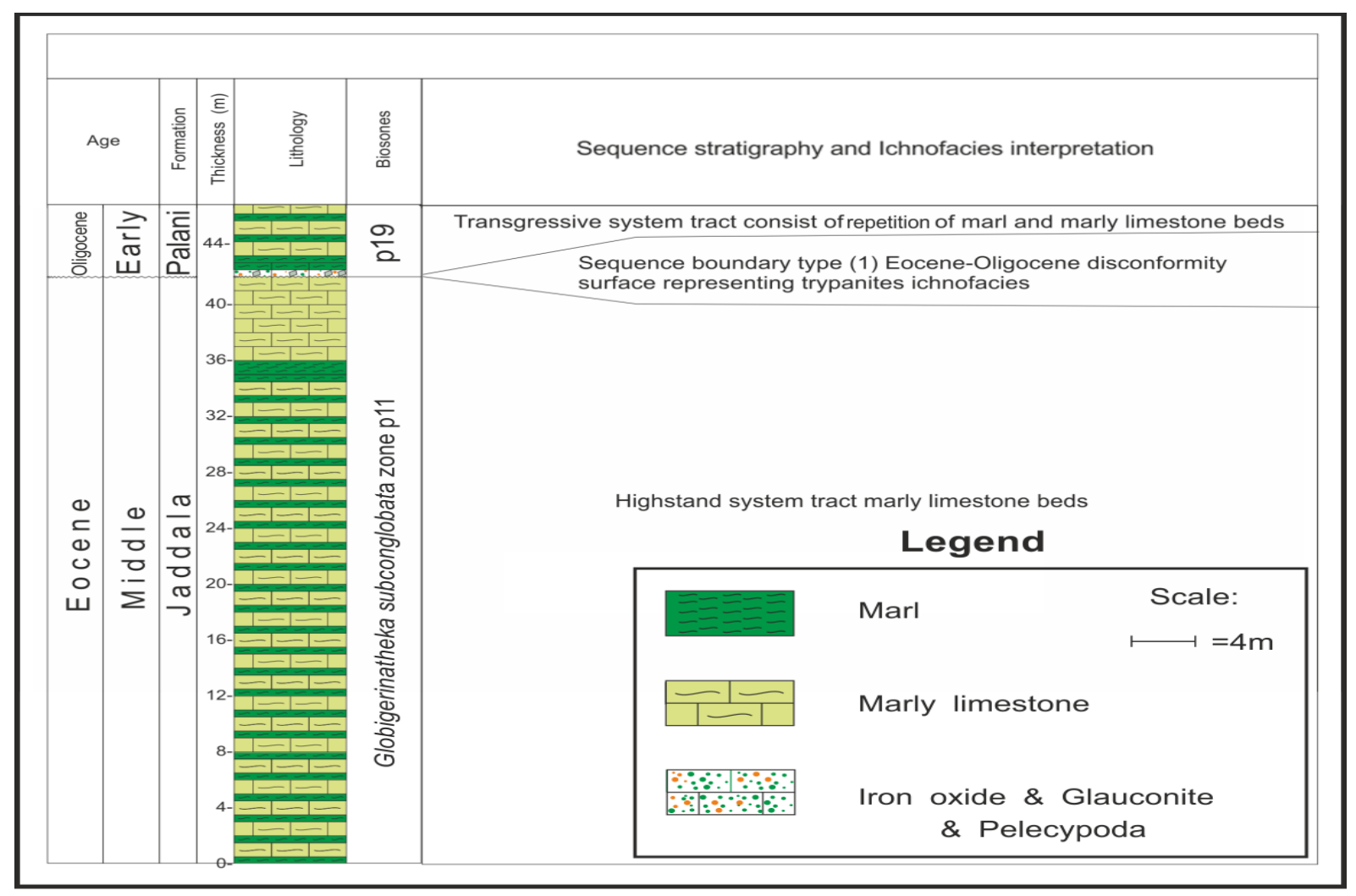

Fig.14: Sequence stratigraphy and ichnofacies interpretation through the Eocene-Oligocene boundary in Sharafiddin section.

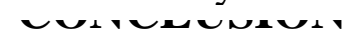

1-The Eocene - Oligocene boundary in Sinjar area is a discontinuity surface located between Jaddala Formation of Early - Middle Eocene age and the overlying Palani Formation of Early Oligocene age and Tarjil Formation of Late Oligocene age.

2-The upper part of Jaddala Formation in Jaddala section is terminated with the existence of Thalassinoides burrows which represent Glossifungites ichnofacies, while in Sharafiddin section this formation is terminated with a hardground limestone bed representing Trypanites ichnofacies.

3-The Palani Formation in Jaddala section started with a conglomerate bed overlain by marl and marly limestone beds, while in Sinjar section it started by a chalky limestone bed containing Skolithos, Planolites, Ophiomorpha within it indicating Skolithos ichnofacies.

4-Two zones are identified within the studied three sections: the Globigerinatheka subconglobata subconglobata Zone (P11) that represents Middle Eocene (Lutetian) age in the upper part of Jaddala Formation; and the Pseudohastigerina micra Interval Zone (P 19) that indicates Upper Early Oligocene age (Rupelian) restricted to Palani Formation.

5-The stratigraphical and paleontological investigation of the Eocene - Oligocene boundary in Sinjar area indicates that during the Middle Eocene (Lutetian) (Zone P11, the uppermost part of Jaddala Formation), the sedimentation stopped, and sudden decline in sea-level occurrred, which may be synchronize with uplift of the 
sedimentary basin due to tectonic events affected the whole Sinjar area. All these effects led to exposure and erosion of the continental shelf, which made this surface a regional disconformity surface and sequence boundary of type 1, that caused a regional hiatus (about 9 my) before it started again at the Early Oligocene (Rupelian) (P19).

6-The Eocene -Oligocene boundaries in Sinjar area witness different situations due to variations in paleoenvironmental conditions affected the three studied sections which can be summarized as:

a- In Jaddala section, the uppermost Middle Eocene sequences of Jaddala Formation accumulated during the highstand system tract. These beds show densely existence of Thalassinoides burrow system. The exposure of the sedimentary basin leads to its cohesion to become a semilithified substrate and then colonized by organisms to form Thalassinoides burrows indicating a Glossifungites Ichnofacies. The boundary is overlain by a conglomerate bed of lag deposits at the lower part of Palani Formation, it represents the lowstand system tract (LST) of the subsequent new sequence that started at the Early Oligocene (Rupelian).

b- In Sinjar section, a chalky limestone bed, which contains Skolithos, Planolites, Ophiomorpha, indicates Skolithos ichnofacies, it directly overlies Eocene-Oligocene boundary representing the lowstand system tract of the Oligocene sequence, the upper boundary of this bed represents a transgressive surface, where above it, and the sediments belonging to transgressive system tract are located.

c- In Sharafiddin section, the Eocene-Oligocene disconformity surface is represented by a hard ground (Trypanites ichnofacies). The boundary in this section represents a sequence boundary and a transgressive surface at the same time due to the absence of the lowstand system tract deposits.

\section{ACKNOWLEDGMENTS}

The authors are grateful to the University of Mosul/College of Science/ Department of geology for providing facilities, which help to improve the quality of this work.

\section{REFRENCES}

Al-Banna, N.Y., 2002: Planktonic foraminiferal biostratigraphy of the Oligocene (Palani and Tarjil formations), Sinjar area. Northwestern Iraq. Raf. J. of Sci., V.13 No.4, pp. 70-80.

AL-Banna,N.Y. and AL-Mutwali,M.M.,2002: Microfacies, Sequence stratigraphy and cooling event of the Oligocene (Palani and Tarjil Formation) at Sinjar area, Northwestern Iraq. Iraqi Journal of Earth Science Vol. 2, No. 2 / 2002, pp. 4858.

Al-Banna, N.Y., and Al-Mutwali, M.M., Ismail, N. R., 2010: Oligocene stratigraphy in the Sinjar Basin, NW Iraq.Geo Arabia, V.15, No.4, pp.17-44.

Al-Hashimi, H.A., J and Amer, R.M., 1985: Tertiary microfacies of Iraq. State Org. Min. Direc.Gene.Geol. Surv. Min. Investig Baghdad, 56 p, 159 plates. 
Al-Mutwali, M. M and Al-Sharbaty, I.H., 2013: Biostratigraphy of Planktonic Foraminifera of Jaddala Formation (Eocene), Bara area, Northwestern Iraq. Iraqi Journal of Earth Science Vol. 13, No. 2, pp.67- 84.

Al-Rubai,H.A., 2017: Stratigraphy andtrace fossils of Eocene-Oligocene boundary at Sinjar area, NW.Iraq. Unpublished M.Sc. Thesis, Mosul university, 123p.

Al-Rubai, H.A. and Al-Mutwali, M.M., 2020: Planktonic Foraminiferal Biosatratigraphy of the Eocene - Oligocene boundary at Sinjar area, NW Iraq, Iraqi National Journal of Earth Sciences, Vol. 20, No. 2, pp. 1-18.

Crimes, T.P., Goldring, R., Homewood, P., van Stuijvenberg, J. and Winkler, W. (1981): Trace fossil assemblages of deep-sea fan deposits, Grunigel and Schlieren flysch (Cretaceous-Eocene, Switzerland). Eclogae Geologicae Helvetiae, 74, 953-995.

Curran, H.A., (ed.), 1985: Biogenic Structures: Their Use in Interpreting Depositional Environments. Soc. of Ec. Pal. Min. special Pub, No.35.

Elewi, A.H., 1982: Stratigraphical and paleontological studies on some Eocene rocks in northern Iraq. (Unpublished M.sc. Thesis). Cairo univ. 197 p.

Frey, R.W. (1975): The Study of Trace Fossils, Springer-Verlag, NeYork, 562 pp.

Ismail, N.R. 2006. Stratigraphical and sedimentological studies of the Middle Eocene - Early Miocene succession in Sinjar Basin, northwestern Iraq. Unpublished PhD thesis, University of Mosul, Iraq,222p

Mac Eachern, J.A., Pemberton, S.G., Gingras, M.K., and Bann, K. L., 2007: The Ichnofacies Paradigm: Afifly- Year Retrospectin. in Trace fossils Concepts, Problems, Prospects, Miller, W. (ed.), Elsevier, pp. 52-77.

Mac Eachern,J.A.,Pemberton,S.G., Gingras,M.K.,Bann,K.L. and Dafoe,L.T.2007: Uses of Trace Fossils in Genetic Stratigraphy. in Trace fossils Concepts, Problems, Prospects, Miller, W. (ed.), Elsevier, pp. 110-134.

Mancini, E.A., and Waters, L.A., 1986: Planktonic foraminiferal biostratigraphy of Upper Eocene and Lower Oligocene strata in southern Mississippi and Southwestern and South-Central Alabama. Journal of Foraminiferal Research, V.16, p.24-33.

Martin, A. J., 2009: Application of Trace fossils to interpreting Paleoenvironments and Sequence stratigraphy. Georgia Geological society Guidebook , Vo.29 , pp. 35 42.

Myrow, P.M., 1995: Thalasinoides and the Enigma of Early Paleozoic openFramework Burrow systems. Palaios, V. 10, pp.58-74. 
Pemberton, S. G. and Frey,R. W.1985: The Glossifungites ichnofacies : modern examples from the Georgia coast USA In: Curran,H.A.(ed.)Biogenic structures: Their use in interpreting depositional environments. Society of Economic Paleontologists and Mineralogists, Special Publications Tulsa, Oklahoma, 35, p.237-259.

Pemberton, S. G., MacEachern, J. A., Frey, R.W., 1992: Trace fossils facies models: environmental and allostratigraphic significance. In: Walker, R.G., James, N.P. (eds.) Facies models response to Sea level change. Geological Association of Canada St. Johns, NF, Canada., pp.47-72.

Pemberton, S.G., Mac Eachern, J. A., and Saunders, T., 2004: Stratigraphic application of substrate- specific ichnofacies: delinating discontinuities in the rock record. in the application Ichnology to Palaeoenvironmental and stratigraphic Analysis, Mc ILRoy, D.(ed.), Geology society, London, special publications, 228, pp.29-62.

Seilacher, A., 1967: Bathymetry of trace fossils. Marine, Geol., 5: pp. 413-428.

Savarda, C.E., Browing, J.V., Krawinkel, H., Hesselbo, S.P., 2001: Firmground ichnofabrics in deep water sequence stratigraphy Tertiary clinoform- toe deposits. New Jersey slope. Palaios 16, pp.294-305.

Toumarkine, M.,and Luterbacher, H.-P., 1985: Paleocene and Eocene Planktic Foraminifera, In Bolli, H.M., Saunders, J.B., and Perch-Nielsen, K. (eds.), Plankton Stratigraphy: Cambridge University Press, Cambridge, p. 87-154.

Udgata, D.B.P., 2007: Glauconite as an indicater of Sequence stratigraphic packages in a lower Paleocene Passine- Margin shelf succession, Centrals Alabama. Unpublishes Msc. thesis, Auburn University, 109P.

VanCouvering,J.A.Aubry,Berggren,W.A.,Bujak,J.P.,C.W.Naeser,C.W.andWieser,T., 1981:The terminal Eocene event and the polish connection, Palaeogeography, Palaeoclimatology, Palaeoecology, V. 36, Issues 3-4, P. 321-362. 